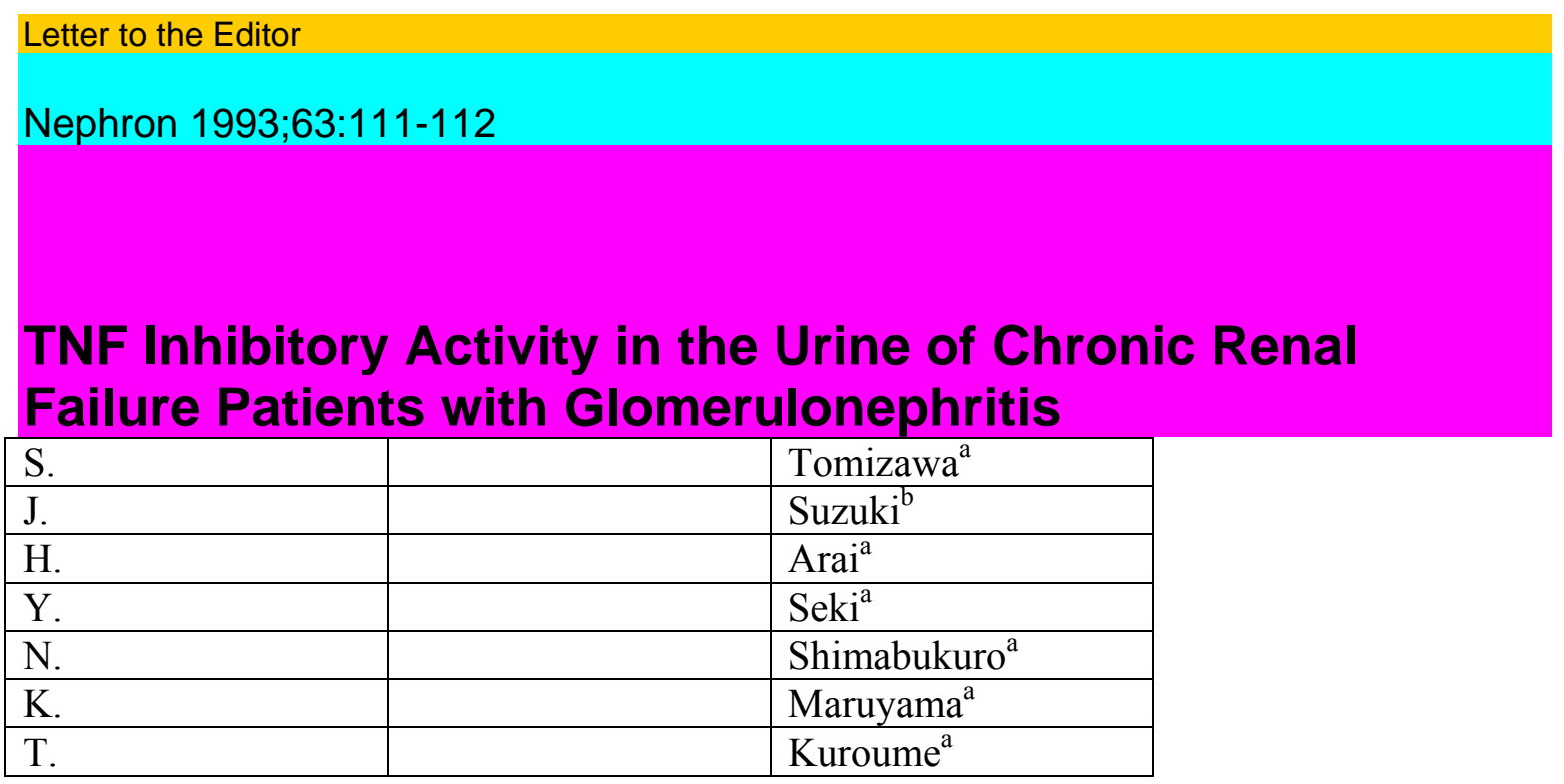

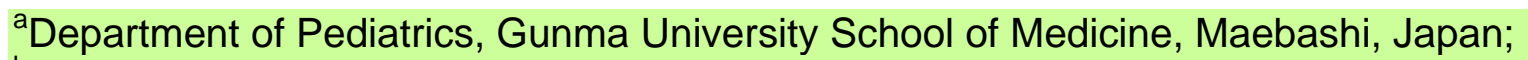
${ }^{b}$ Biotechnology Research Laboratories, Teijin Tokyo Research Center, Teijin Ltd, Hino, Japan

S. Tomizawa, Department of Pediatrics, Gunma University School of Medicine, Showamachi 3-39-15, Maebashi, Gunma (Japan)

Dear Sir,

It is supposed that renal diseases, especially glomerulonephritis (GN), are caused by dysfunction of immunological reaction. Recently, a correlation between cytokine levels such as TNF, IL-1, IL-6 and triggering or aggravation of the renal diseases has been reported [1-5], while the existence of urinary and serum inhibitors or binding proteins against cytokines such as TNF or IL-1 and their biological activity have been described [6-8].

In this paper, we examine the TNF inhibitory activity in the urine of both chronic renal failure (CRF) patients with congenital renal diseases and those with GN, in order to determine if TNF and/or TNF inhibitors are related to CRF with GN.

Ten milliliters of urine were freshly obtained from a pool of $10 \mathrm{CRF}$ patients ( 6 boys, 4 girls, mean age 12.3 years, range 6-18). Two of these were suffering from polycystic kidney, 1 from hypoplasia, 1 from juvenile ne-phronophthisis, 1 from oligomeganephronia and 5 from GN. Thirty-three healthy children without any inflammatory diseases or renal diseases aged 10.8 years (range $8-16$ ) served as normal controls.

All urines were centrifuged $(1,800 \mathrm{~g}, 5 \mathrm{~min})$ to remove the insoluble materials. Each $2 \mathrm{ml}$ of supernatants was concentrated by ultrafil-tration with a membrane of a molecular-weight cutoff of $10 \mathrm{kD}$ (Centricon 10; Ami-con Inc.), and four-fold condensed urines were used for bioassay of TNF inhibitory activity. TNF inhibitory activity was measured in an assay of cytotoxicity using the TNF-sensitive cell line L929 [9]. Briefly, $4 \times$ 105 cells $/ \mathrm{ml}$ in $10 \%$ fetal calf serum-RPMI containing $2 \mu \mathrm{g} / \mathrm{ml}$ of actinomycin D was prepared, and $100 \mu \mathrm{l}$ of cell suspension was inoculated in 96-well microtiter plates. After $2 \mathrm{~h}$ of incubation in $5 \% \mathrm{CO}$, at $37^{\circ} \mathrm{C}, 50 \mu \mathrm{l}$ of samples and $50 \mu \mathrm{l}$ of $2.6 \mathrm{ng} / \mathrm{ml}$ recombinant TNF (specific activity $3 \times 107 \mathrm{U} / \mathrm{mg}$ [10] in $10 \%$ fetal calf serum-RPMI were added to each well, followed by $18 \mathrm{~h}$ of incubation in $5 \% \mathrm{C} 02$ at $37^{\circ} \mathrm{C}$. After washing with phosphate-buffered 
saline, viable cells were stained by crystal-violet then solubilized with $100 \mu \mathrm{l}$ of $0.5 \%$ sodium dodecyl sulfate, and absorbance at $595 \mathrm{~nm}$ was measured.

The TNF inhibition rate was calculated by the following formula:

[OD595]TNF only

\section{$\times 100(\%)$.}

$\mathrm{TNF}$ inhibition rate $=\left[\mathrm{OD}^{1 / 8} 8 \boldsymbol{c}^{7 / 8}\right] \mathrm{TNF}+$ inhibitor-

[OD595]TNF free-[OD5 < )5]TNF only

A slight TNF inhibitory activity was found in the urine of healthy children, whereas it was considerably higher in the urine of CRF patients $(\mathrm{p}<\mathrm{O} . \mathrm{Ol})$. Among the CRF patients, the urine from the patients with GN showed high percentages of TNF inhibitory activity $(\mathrm{p}<$ 0.05; fig. 1).

As the functions of TNF have been well characterized in vitro, it is supposed that this cytokine might be involved in acute/chronic inflammatory diseases [11]. In our experiment, the urine from CRF patients with GN, having shown mesangial proliferation and chronic

inflammatory changes, clearly demonstrated a high TNF inhibitory activity. The fact that IL6 is the mesangial cell growth factor and its production is induced by TNF has been reported $[4,5]$. Furthermore, serum and urinary TNF binding proteins in CRF patients have been shown to act as regulators of the bioacti-vities of TNF $[6,7]$. Thus, it is suggested that the urinary excretion of TNF inhibitors in CRF patients with GN might be induced by overproduction of TNF.

Studies about the TNF inhibitor are in progress. From the amino acid sequences deduced from cDNA sequences of TNF receptors, TNF inhibitors in the urine were supposed to be the truncated forms of TNF receptors [12-14]. We have also confirmed that the TNF inhibitory activity in the urine of one patient was caused by two TNF inhibitors. One was derived from a TNF receptor, $\mathrm{p} 55$, and the other might be different from a soluble TNF receptor, $\mathrm{p} 75$ [unpubl. data]. We are now on the way to purify large amounts of these inhibitors and to clarify the in vivo effects of the inhibitors from the patient.

$100-1$

Fig. 1. TNF inhibition rate of urine samples from the patients with CRF and healthy controls. The mean standard error of TNF inhibition rate was $5.5 \pm 1.0 \%$ in normal controls $(\mathrm{n}=33, \bullet)$ and $32.0 \pm 7.5 \%$ in CRF patients $(\mathrm{n}=10 ; \mathrm{p}<0.01)$; in CRF with $\mathrm{GN}(\mathrm{n}=5, \mathbf{m})$ and CRF with congenital renal diseases $(n=5, O)$, it was $46.1 \pm 11.1$ and $17.4 \pm 4.3 \%$, respectively (p $<0.05)$.

\section{References}

Wardle EN: Cytokine growth factors and glomerulonephritis. Nephron 1991;57:257-261. Bertani T, Abbate M, Zoja C, Corna D, Perico N, Ghezzi P, Remuzzi G: Tumor necrosis factor induces glomerular damage in the rabbit. Am J Pharmacol 1989;134:419^30.

Brennan DC, Yui MA, Wuthrich RP, Kelly VE: Tumor necrosis factor and IL-1 in New Zealand black/white mice. Enhanced gene expression and acceleration of renal injury. $\mathbf{J}$ Immunol 1989;143:3470-3475.

Horii Y, Maraguchi A, Iwano M, Matsuda T, Hirayama T, Yamada H, Fujii Y, Dohi K, Ishikawa H, Ohmoto Y, Yoshizaki K, Hirano T, Kishimoto T: Involvement of IL-6 in mesangial proliferative glomerulonephritis. J Immunol 1989;143:3949-3955. 
Hirano T, Shizuo A, Taga T, Kishimoto T: Biological and clinical aspects of interleukin-6. Immunol Today 1990;11:443-449.

Peetre C, Thysell H, Grubb A, Olsson I: A tumor necrosis factor binding protein is present in human biological fluids. Eur J Haematol 1988; 41:414^*19.

Olsson I, Lantz M, Nilsson E, Peetre C, Thysell H, Grubb A, Adolf G: Isolation and characterization of a tumor necrosis factor binding protein from urine. Eur $\mathrm{J}$ Haematol 1989;42:270-275.

Hession C, Decker JM, Sherblom AP: Uromo-dulin (Tamm-Horsfall glycoprotein): A renal ligand for lymphokines. Science 1987; 237: 1479-1484.

Seckinger P, Isaaz S, Dayer JM: A human inhibitor of tumor necrosis factor- $\alpha$. J Exp Med 1988;167:1511-1516.

10 Nakamura S, Masegi T, Kitai K, Ichikawa Y, Kudo T, Aono R, Horikoshi K: Extracellular production of human tumor necrosis factor- $\alpha$ by Escherichia coli using a chemically synthesized gene. Agric Biol Chem 1990;54:3241-3250.

Fiers W: Tumor necrosis factor: Characterization at the molecular, cellular and in vivo level. FEBS Lett 1991;285:199-212.

Loetscher H, Pan YCE, Lahm HW, Gentz R, Brockhaus M, Tabuchi H, Lesslauer W:

Molecular cloning and expression of the human $55 \mathrm{kd}$ tumor necrosis factor receptor. Cell 1990; 61: 351-359.

Schall TJ, Lewis M, Koller JK, Lee A, Rice GC, Wong GHW, Gatanaga T, Granger GA, Lentz R, Raab H, Kohr WJ, Goeddel DV: Molecular cloning and expression of a receptor for human tumor necrosis factor. Cell 1990;61:361-370.

Smith CA, Davis T, Anderson D, Solam L, Beck-mann MP, Jerzy R, Dower SK Cosman D, Goodwin RG: A receptor for tumor necrosis factor defines an unusual family of cellular and viral proteins. Science 1990;248:1019-1023.

112

Tomizawa/Suzuki/Arai/Seki/ Shimabukuro/Maruyama/Kuroume

TNF Inhibitory Activity in GN 